\title{
Chapter 7 \\ Central Asia in Transition: Social \\ Contract Transformation in Nazarbayev \\ and Post-Nazarbayev Kazakhstan
}

\author{
Nygmet Ibadildin and Dinara Pisareva
}

\subsection{Introduction}

On March 22, 2019, during the festive mood of celebration of the national spring holiday of Nowruz, among the citizens of Kazakhstan, a sense of disorientation and confusion arose. Politics and people have for long existed in separate domains in Kazakhstan, but on March 19, Kazakh President Nursultan Nazarbayev made a surprise announcement about his decision to resign with immediate effect and the surprising news that Kazakhstan's capital, Astana, was to be renamed Nur-Sultan in Nazarbayev's honor. Kazakh Parliament quickly approved the initiative put forward by then acting and later elected active President Kassym-Jomart Tokayev, who previously served as chairman of the Senate. The public reaction to Nazarbayev's resignation and the renaming of the capital was mixed. While some Kazakhs were optimistic about the prospects for liberalization and political change, others were less so. Most people, however, hoped to see a calm, managed political transition from the old authoritarian regime to a new one.

Hence, this article looks at the evolution of the modern political history of Kazakhstan, from the collapse of the Soviet Union to Nazarbayev's resignation, using the social contract theory where key events of domestic politics are interpreted as a part of implicit agreement between elites and people. Back in 1991, there were hopes for possibility of democratic transition in Kazakhstan. But rapid strengthening of presidential rule and several forceful dismissals of Parliament in mid-90s clearly signaled that democracy was not among top priorities of Nazarbayev's regime. As

\footnotetext{
N. Ibadildin $(\varangle)$

KIMEP University, Almaty, Kazakhstan

e-mail: nygmet@kimep.kz

D. Pisareva

Australian National University, Canberra, Australia

e-mail: dinara.pisareva@anu.edu.au
} 
the president himself said during the 2015 presidential elections, "democracy is not the starting point of our way, it is the final point of our destination" (Tengri News 2015).

The social contract that was instead offered by Kazakh elites to the people can be summarized as a focus on economic development and a provision of social benefits in exchange for unchallenged political rule and opportunities for the elites' personal enrichment. During the first decade of independent Kazakhstan, there was an increasing power concentration in the hands of the president and his close circle. However, as the country was becoming less democratic, there was no widespread public dissatisfaction as people were mostly preoccupied with survival and moving forward following the rough socioeconomic transition of the early 1990s, and therefore, one thing they wanted the most from their political elites was not to get in their way.

Until 2001, there was still a limited possibility for outsiders to gain a certain amount of political influence in the system, but the 2001 "revolt of new Kazakhs" led to restricting political access only to those who had proved themselves truly loyal to Nazarbayev. The 2001 events revealed that the young post-Soviet Kazakh elite was not entirely satisfied with a system where only Nazarbayev's inner circle had access to real political influence and resources, which prompted some of newly emerged businessmen and politicians to attempt a "revision" of the existing social contract by raising demands for reforms and democratization, which then soundly failed.

The president's extremely harsh response to the young reformers showed he viewed the revolt as a violation of the personal loyalty expected of the businessmen and government officials who made their fortune during his rule. It also signaled there would be no liberalization of the political system or any revisions of the social contract. However, as long as high oil prices supported Kazakhstan's economic growth, there was no widespread dissatisfaction with authoritarian politics from the public.

The frustration that existed was primarily concerned with the failure to modernize and diversify Kazakhstan's economy, with the ineffective state development programs, and with the corrupted government. The 2008 global financial crisis and volatilities on the oil market demonstrated that no hydrocarbon exporter, including Kazakhstan, was safe from macroeconomic shocks. A series of socioeconomic downfalls-rapid currency devaluation during 2014-2015 with the tenge losing more than $100 \%$ of its value and performing worse than the Ukrainian hryvna or the Russian rouble, and mass land reform protests in 2016 - revealed decreasing levels of trust in Kazakhstan's government and an emerging realization that the old social contract was no longer perceived as legitimate.

By 2019, there was a lot of speculation about the future political trajectory of Kazakhstan and how the transition model would look in the Kazakh case. Nazarbayev had opted for a "Yeltsin" model in which he publicly announced his resignation, raising a lot of discussion about the motivations behind this choice. Following this development, by 2019 Nazarbayev had limited options as two fundamental narratives that had provided legitimacy to his rule-strong economic performance and political stability-failed to seem convincing. In terms of economic performance, the global fall of oil prices revealed the weakness of Kazakhstan's non-oil economic sectors 
and its failure at modernization. Political stability and associated social security have also been questioned after the case of police violence in Zhanaozen in 2011 and mass arrests following land reform protests in 2016.

\subsection{The Social Contract Theory in the Post-Soviet Space}

Social contract is one of the most well-known political theories that introduce the concept of the implicit contract among citizens who are willing to accept limitations on their natural freedoms in exchange for security and protection of their rights provided by the government. While the idea of the social contract can be traced as far back as to ancient Greece, it became truly popular in the eighteenth century thanks to political philosophers such as Thomas Hobbes, John Locke, and JeanJacques Rousseau each of whom presented their own vision of a social contract that legitimized the existence of the modern state (Boucher and Kelly 1994). Even though the social contract theory takes its origins in Western political philosophy, its variations can be clearly observed in the non-Western world, such as the Soviet Union and post-Soviet states. For example, resource-rich Russia and Kazakhstan, where political regimes' legitimacy has been based on a very special sort of social contract between elites and society, can be described as a "rentier social contract" where the "state provides goods and services to society (...) while society provides state officials with a degree of autonomy in decision-making." The core of such a political system is the "feudal appropriation of unearned income" and its further distribution by elites (Sakwa 2014).

Earlier in Soviet times, a similar type of social contract was observed during Leonid Brezhnev's period (1964-1982) when, as a popular Soviet joke told it, "we [people] pretend to work, they [government] pretend to pay us" (Bacon 2002). Breslauer (1978) named such a type of political regime as "welfare-state authoritarianism," characterized by a "pattern of political, social, and material benefits offered by the ruling authorities... both to regulate relationships between themselves and to elicit compliance and initiative from groups in society." Jowitt (1992), however, described such a type of social contract in harsher terms as a "protection racket" between non-equal parties of a "parasitical party" and a "scavenger society."

Jowitt's description of Brezhnev's period is a reminder of the time, aptly named as zastoi (stagnation) by Russian historians, that was full of contradictions such as both economic stagnation and increasing consumption due to rising oil prices, people's alienation from the ruling CPSU (Communist Party of Soviet Union), coupled with formal compliance with its rules and ideology. It is perhaps not an accident that Russia under Vladimir Putin's rule has often been compared to Brezhnev's period because of the apparent similarities of the social contact in both the USSR's centralized system and contemporary Russia's market economies (Pisano 2014).

However, it should be recognized that Russia's social contract has been transformed to incorporate not only an "implicit trade-off" between social benefits and political control, but also neo-imperialist sentiments and assertive foreign policy that, 
following Crimea's annexation in 2014, have become the main source of the regime's legitimacy. Russia's foreign policy is a big part of its post-imperial syndrome where modern Russia still harbors a great deal of resentment and regret over lost geopolitical power and territories. As Vladimir Putin famously said in 2005 about the collapse of the Soviet Union, for him it was the "greatest geopolitical catastrophe of the XX century" (Reuters 2018).

In comparison with Russia, Kazakhstan has been an example of classic "welfarestate authoritarianism" in the post-Soviet space, with several important periods in its post-independent history that could have been roughly described as post-Soviet opening, increasing centralization of power, revolt of new elites, and further authoritarian consolidation.

\subsection{Nazarbayev's Key Periods and Changes}

Post-Soviet Kazakhstan is traditionally considered as the leader of the Central Asian region due to its size, economic performance, and abundance of natural resources. While it might outperform its neighbors in economic terms, its political regime is quite similar to the rest of authoritarian Central Asian states (with the notable exception of semi-democratic Kyrgyzstan). Zakaria (1997) included Kazakhstan in the list of so-called illiberal democracies defining it as a "near tyranny" where certain electoral procedures are preserved, but the essence of the regime is an authoritarian one.

For a while, the discourse of the economic success of President Nazarbayev's leadership has been the main basis for the social contract with people who judged government by the "material benefits it provided to its citizens" (Olcott 2010b). To a large extent, such attitudes could have been explained by the socioeconomic hardships of early 1990 when material security and stability became the top priority for the first post-Soviet generation. Kazakhstan's early years of independence were challenging, to say the least. From 1991 to 1994, Kazakhstan's GPD fell by 60\%, while the annual inflation rate in 1994 was $1800 \%$ (Akhanov and Buranbayeva 1996).

Such a social contract ultimately depends on citizens' long-lasting indifference to the political process and the state's non-interference into private lives, which for a while has been a satisfactory agreement for Kazakhstan's society (Dave 2007). However, since the 2010s there have been indicators of rising popular discontent with uncertainty in the political regime's future, the perceived compromises on sovereignty with Russia and China, the rapid currency devaluation, and the economic development that suffered from a drop in global oil prices.

In the beginning of post-independent Kazakhstan, there was a brief three-year period when post-Soviet elites "at least flirted with the idea of a transition to democracy" (Olcott 2010b). Nazarbayev selected a government of reformers to promote the liberalization of the economy and prepare the first post-independent constitution that came into force in 1993 and which established a parliamentary republic with 
clear separation of powers, provision of Parliament with real law-making powers, and a ban on president's service beyond two terms.

At the same time, Nazarbayev convinced the Supreme Council (that acted as Parliament) that there was a need for strong presidential power to guide the country through the process of reforms, and he subsequently acquired their approval (Cummings 2005). As the Supreme Council at the time was an independent branch of power, there were often confrontations between Nazarbayev and Chairman of the Supreme Council Serikbolsyn Abdildin, who did not support the stabilization and privatization programs suggested by the International Monetary Fund. These ongoing conflicts resulted in a dissolution of the Supreme Council in December 1993 under the pretext that it was not legitimately elected (it was elected in March 1990 during the Soviet Union's existence) and with new parliamentary elections scheduled for 1994.

However, the Parliament elected in 1994 was also dissolved in 1995 as the elections were again called illegal by Nazarbayev. In the absence of Parliament, presidential powers were expanded further due to the pass of a special decree that gave Nazarbayev the power to declare a state of emergency, initiate referendums, and appoint personnel. Nazarbayev also called for two public referendums in 1995, the first one extending his rule until 2000, and the second one introducing the adoption of a second constitution that considerably strengthened presidential power and is still in force today. One of Nazarbayev's fierce critics, Abdildin, called the dissolution of the Parliament in 1995 and the following changes in the constitution along with the consolidation of Nazarbayev's power a coup d'état (Akkuly 2011).

As it can be seen, the first five years of independence determined Kazakhstan's political regime and its trajectory of authoritarianism that came into full force in the early 2000s. At that time, most elites agreed to Nazarbayev's demand for power consolidation and weakening of legislative power, not unlike in Russia where Boris Yeltsin was facing similar problems with the Duma (Russian Parliament). The confrontation between legislature and executive in Kazakhstan and Russia in the early years is a typical example of one of the most common dilemmas that emerge in the countries in transition that can be summarized as "democratization vs. governability." This dilemma describes the complexity of multiple transitions of political and economic levels when it is difficult to combine popular rule and take into account plural preferences with the necessity to implement radical economic reforms (Hobson and Kurki 2012).

During such periods, the necessity to overcome an economic crisis under consolidated rule usually outweighs the commitment to a democratic regime, as happened in Kazakhstan and Russia in the 1990s. Kazakhstan had experienced one of the toughest economic transitions following the collapse of the Soviet Union and its forced exit from the ruble zone. The popular motto of Kazakhstan's leader, "economy first, politics later," that Nazarbayev proclaimed during his 2011 inaugural speech certainly owed some of its origins to this chaotic time of post-communist transition when the shortcomings of democratization were justified by the necessity to introduce radical economic reforms (Aitken 2010). 
The second decade of the 1990s was also followed by increasing concentration and centralization of presidential powers with further restrictions on democratic freedoms. Nazarbayev proceeded with the weakening of government branches by abolishing certain ministries and state committees (Cummings 2005). At this stage of his political career, Nazarbayev faced a major challenge from former Prime Minister Akezhan Kazhegeldin (1994-1997) who openly accused Nazarbayev's regime of corruption and who intended to rival Nazarbayev in the next presidential elections, but had to leave the country and seek sanctuary in the UK because of accusations of corruption and the possibility of arrest. Same as Nazarbayev, Kazhegeldin was an experienced Soviet party member who was a head of several executive committees in eastern Kazakhstan.

In 1997, Kazhegeldin was replaced by Nurlan Balgimbayev, the head of the state oil company, indicating the growing importance of the oil and gas industry for Kazakhstan (Olcott 2010b). During the Soviet times, Balgimbayev was chief engineer of Zhaykneft oil refinery, working for the Soviet Ministry of Oil and Gas. After the collapse of the Soviet Union, Balgimbayev spent a short time in the USA doing an internship at Chevron. In post-independent times, Balgimbayev had occupied both positions as Minister of Oil and Gas and as president of Kazakhoil. Balgimbayev was the one who invited the so-called young Turks into the government, introducing young successful businessmen who had managed to achieve success during the transition and privatization of the early 1990s. Many of them would play a crucial role in forming a challenge to Nazarbayev's regime in the 2000s, such as Mukhtar Ablyazov, Oraz Zhandosov, Galymzhan Zhakiyanov, Alikhan Baimenov, and Bulat Abilov. Many of them worked with Kazhegeldin as well and made their fortune under privatization programs and the initial development of capitalism.

The early presidential elections of 1999 were negotiated with Parliament and concluded with Nazarbayev's victory of 79\%. By that time, Kazakhstan was shaped into a political system most suited to elites' preferences, consisting of strong presidential power, tightly controlled opposition and censored mass media. But this transition to an authoritarian regime was not smooth, as the ruling regime had to overcome resistance from opposition actors using oppressive means that considerably worsened the reputation and legitimacy of the 1999 elections and attracted international criticism. Moreover, the broad extent of corruption of Nazarbayev's regime was publicly revealed and highlighted during the struggle between him and opposition in the second half of the 1990s.

2001 was a crucial moment for Nazarbayev's political regime, as for the first time since Kazakhstan's independence his monopoly on political power was openly challenged by new Kazakh elites. The irony was that these Western-oriented selfmade businessmen who gained their assets during privatization in the early 1990s were a class created by Nazarbayev's regime itself, comparable to Russia's oligarchs that emerged during Yeltsin's rule. In other words, the regime's main opposition was also a direct creation of this regime. They all possessed a considerable amount of wealth and influence, but their power was still far from those of the inner circle or Nazarbayev's clan who controlled all resources and distribution of rents. 
Two prominent figures from Kazakhstan's political elites were at the root of this conflict, Nazarbayev's deceased son-in-law and former husband of Nazarbayev's oldest daughter Dariga Nazarbayeva, Rakhat Aliyev, and former Minister of Energy, Industry, and Trade Mukhtar Ablyazov, whose assets Aliyev tried to seize (Olcott 2010a). At that time, Aliyev's influence as the deputy head of the Committee of National Security was almost limitless due to Nazarbayev's support, so virtually nobody's property was secure from being seized. The desire to constrain Aliyev's influences was one of the main factors behind the creation of the first political party not affiliated with the ruling regime, the Democratic Choice of Kazakhstan (DVK).

DVK was an aggregation of various interests represented by the new elites frustrated with their outsider status, distance from decision-making, and inability to gain genuine political influence. On the one hand, former participants such as businessman Bulat Abilov said their true agenda was to introduce "changes" to the corrupt neo-patrimonial system based on the dominance of Nazarbayev's clan, while proNazarbayev's supporters such as Nazarbayev's political advisor Yermukhamet Yertysbaev claimed that the DVK was created by Ablyazov to gain an upper hand over Aliyev and he had no further political ambitions, "Ablyazov himself confessed in his unpublished memoirs that he did not look further [than dismissing Aliyev] and did not plan to make any further moves" (Akkuly 2009). Each of DVK's leading actors joined the movement with his own agenda, and there was hardly a common goal shared by all of them.

This lack of unity and diverse interests turned out to be fatal for the party's future, and in 2002, the party split into the moderate Ak Zhol led by Altynbek Sarsenbayev, Oraz Zhandosov and Alikhan Baimenov, and "radicals" Mukhtar Ablyazov and Galymzhan Zhakiyanov. Both Ablyazov and Zhakiyanov were arrested in 2002 and sentenced to prison over accusations of corruption. Ablyazov was released in 2003 after he allegedly promised not to return to politics and was even appointed as Chair of Board of Directors of Bank Turan Alem (BTA). However, he did not stay in a favorable position for long as in 2009 he fled the country, followed by the state's accusations of him illegally moving the bank's capital out of Kazakhstan and abusing his position as chair of the board by giving loans to companies associated with him (Trifonov and Rubnikovych 2010). Zhakiyanov suffered a harsher fate, spending his sentence in worse conditions. He was released only in 2004 due to serious health concerns and international pressure (Olcott 2010b). After the 2004 elections, he left the country and there is scarce information about him in the public domain since 2008.

Nazarbayev's harsh reaction to the emergence of this new pro-reformist group that demanded changes has been explained by his fear that the opposition wanted to overthrow his regime and him personally. As Abdildin remembered when he asked Nazarbayev in 2003 why he did not want to release Ablyazov and Zhakiyanov, Nazarbayev responded with indignation, "They almost brought me down" (Akkuly 2009). DVK's emergence in 2001 demonstrated there was no uniform consensus about the existing social contract among Kazakhstan's new elites, and those who 
were left outside the inner circle of Nazarbayev's clan were not satisfied with the distribution of political influence. Although Nazarbayev succeeded in dividing and suppressing the newly born opposition, this was not the last challenge to the dominance of Nazarbayev's clan in Kazakhstan's politics.

After numerous public scandals that involved Rakhat Aliyev in 2001, he was sent as an ambassador to Austria. The main source of Nazarbayev's disappointment with Aliyev was the revelation that Aliyev was planning a coup d'état to take Nazarbayev's place. In 2007, Parliament approved an amendment to the constitution that allowed Nazarbayev to be reelected without any limitations. At that time, Aliyev started openly opposing Nazarbayev, saying that "a younger, more open generation should come to power" (Smale 2007). Ironically, he almost repeated Nazarbayev's own words from twenty years before, "A leader shouldn't keep one post for decades... a desire to look legitimate in the end creates a perception of sanctity. There is a need for a time limit. Only a democratic society would be a guarantee of a stable happy future" (Radio Azattyq April 2, 2008).

In response to Aliyev's political statements, Kazakhstan started a criminal investigation, accusing Aliyev of kidnapping and torturing two bankers from Nurbank. The government filed a request for Aliyev's extradition from Austria, a request that Vienna declined, providing Aliyev with political sanctuary (Gorst 2007). Kazakhstan's military court stated that Aliyev was guilty in absentia, quickly followed by Dariga Nazarbayeva's divorce from Aliyev. Aliyev's most visible strike against Nazarbayev was the publication of a book with the telling name The Godfather-in-Law, a publication that provided, in great details, information about the role of corruption and bribes in Kazakhstan's political system, while directly naming many high-ranking people who were forced to pay large tributes to Nazarbayev. The dissemination of this book was prohibited in Kazakhstan under the pretext of protecting the privacy of the people mentioned in the book. Aliyev's struggle against Nazarbayev ended abruptly in February 2015 when he was found hanging in his prison cell in Vienna while awaiting trial for murder charges (Weber and Groendahl 2015). Although there were certain suspicions surrounding this sudden death, Austrian investigators officially declared that Aliyev committed suicide (BBC News February 25, 2015).

Aliyev's case became a psychological point of departure for Nazarbayev's regime, after which it had significantly narrowed the circle of ruling elites and shed all features of a hybrid regime with limited pluralism, turning into fully consolidated authoritarianism.

According to Freedom House, Kazakhstan's democracy score has been gradually declining since the early 2000s, with the exception of 2009 when Kazakhstan introduced some liberalizing amendments to electoral and media law in advance of its much-sought OSCE's chairmanship in 2010 (Freedom House n.d.). In general, already by the mid-2000s Kazakhstan was a consolidated authoritarian regime, and after the 2001 failure of democratic opposition, there were no large-scale challenges to the existing regime from the side of elites.

The lack of democratic procedures and alternatives to Nazarbayev's regime did not seem to be a concern for Kazakhstan's population, with one prominent exception in 2011 when there were protests by oil workers in the small town of Zhanaozen in 
Western Kazakhstan. Political authorities took the decision to employ force and as a result of violent clashes with police 16 people died. The situation was followed by Nazarbayev's declaration of a state of emergency in the region that basically gave unlimited authority to law enforcement for brutal interrogations, torture and arrests (Nurumov and Vashchanka 2016). On the one hand, these protests were related to the specific issue of salaries in oil sector, and however, on a higher level, it was also "emblematic of the overall social and economic deterioration and failures of the political system, in other words, of what has been called 'authoritarian modernization", (Malashenko 2013).

Much of the regime's legitimacy during the late 2000s came to rest on its economic performance, which largely depended on high oil prices and left the economy vulnerable to macroeconomic volatility. Declining oil prices and devaluation of the Russian rouble in 2014 resulted in Kazakhstan's decision to cancel the fixed exchange rate for tenge, immediately followed by a sharp devaluation (Kourmanova 2015). During 2014-2015, the tenge was called the world's "most volatile" currency, losing more than $100 \%$ of its value in relation to the USD something that did not happen even in conflict-torn Ukraine (Seputyte and Gizitdinov 2015). Although the official position was that the devaluation would the benefit the economy as it would increase the competitiveness of the private sector, the real beneficiaries were export-oriented companies whose interests were lobbied by the government.

The 2014-2015 devaluation raised a high level of dissatisfaction among people. However, there were almost no public protests with the only exception of Almaty where a few dozen people gathered to protest during the first devaluation wave in 2014 (RFE Kazakh Europe 2014). Genuine social tensions broke out in 2016 when Parliament passed a law that allowed foreigners to rent agricultural land for 25 years, triggering mass protests not only in Almaty and Astana but also in small towns across all of Kazakhstan (BBC News April 28, 2016). Although the law itself was quite progressive and did not include permission for foreigners to purchase land, people clearly did not trust the government to hold its end of bargain and were concerned it would mean foreign investors (mostly Chinese) would come to monopolize Kazakhstan's land.

Such an interpretation of the government's actions first and foremost signaled the high level of distrust in the society of the government and political elites (Toleukhanova 2016). Many of the protesters were detained, but no deadly force was used this time. Nazarbayev took the decision to put a moratorium on land reform until December 31, 2016, and ordered a Presidential Commission on land reform that included not only public officials, but also actors from civil society and NGOs (Sholk 2016). It was obvious that such large-scale protests took the president and elites by surprise and raised serious concerns as Nazarbayev in his speech emphasized the overall importance of national unity and not letting a Ukrainian scenario happen in Kazakhstan (Reuters May 1, 2016).

2016 was also the last year of parliamentary elections to be closely observed by the OSCE mission. The mission noticed there were still many problems with the conduct of the electoral process in Kazakhstan. In the words of Marietta Tidei, special coordinator and leader of the short-term OSCE observer mission, "It is clear 
that Kazakhstan still has a long way to go toward fulfilling its election commitments... the ruling party had a clear advantage over others in these elections and, while the parties were generally able to campaign freely, genuine political choice remains insufficient" (OSCE 2016).

2014-2016 was also the period during which it became apparent there was masslevel dissatisfaction with how things were done under the existing political system. Nazarbayev and elites had also received this warning signal and tried to introduce some limited reforms and development programs.

\subsection{Weak Social Contract in the Late Nazarbayev Period}

In March 2015, during presidential elections, Nazarbayev said there was "colossal work" done in Kazakhstan, with GDP per capita increasing from $\$ 600$ to $\$ 13,000$ and the economy growing 21 times larger compared to 1991 (Tengri News March 20, 2015). The economic achievements of post-independent Kazakhstan have been the main reason why some regional experts consider it as a successful political model, especially in the context of much-troubled post-Soviet transition.

The less-talked aspect, however, is that such economic growth has been dependent on the exploitation of natural resources. Although the government has invested in infrastructure and institutions, it has still failed to develop non-resource sectors of the economy, tackle corruption and introduce effective governance (Hoen and Irnazarov 2012). In social contract theory, there is always "a moment in the history of a society when it will be obvious to enough people... that the government has betrayed its trust and has to go" (McClelland 1996). Although Kazakhstan still has a long way to go till such a moment, there is a feeling of deteriorating trust in the government and its capacity to provide for the people. In July 2016, the Center of Political and Social Research Strategy conducted a public survey in Kazakhstan to assess the size of population that desired socioeconomic changes, and the results were quite telling, as more than $75 \%$ of participants wanted to see changes (Tatilja 2016).

At the end of 2015, Nazarbayev introduced the "100 Steps to Five Reforms" program, designed to establish a professional government apparatus, the rule of law, industrialization and economic growth, transparent accountable government, national identity and unity (Kazinform 2015). According to Nazarbayev, these measures and laws would be an adequate response to the global economic crisis and would restore economic growth and social stability (Tengri News, January 6, 2016). Moreover, these reforms would allow Kazakhstan to achieve the ultimate goal of becoming one of the thirty most developed countries in the world by 2050, which is reflected in another state program, "Kazakhstan-2050."

However, such optimistic scenarios have not been supported by experts such as Oraz Zhandosov (one of the founding members of the Democratic Choice of Kazakhstan in 2001 who chose to stay with moderates after the split in the democratic movement). He predicts that unless there are radical changes in the government, the approximate economic growth during 2017-2021 will be 1\% per year, which means 
Kazakhstan's agenda of getting to the list of most developed countries is highly unlikely (Forbes 2016). Any radical changes in Kazakhstan's political system are unlikely to happen due to the lack of recognition of the problems among the ruling elites. Nazarbayev himself always emphasized that the roots of the crisis were external, due to "falling energy prices... difficult international situation, confrontations between leading powers," and called for people not to look for guilty people among the elite, stating "I would like to say to those who will try to politicize the situation and look for someone to blame, this [crisis] is a global process that no country could influence" (Tengri News January 20, 2016).

\subsection{Nazarbayev's Resignation in 2019}

Following Nazarbayev's unexpected resignation in early 2019, one of the main questions was why he decided to follow in Boris Yeltsin's steps and voluntarily step down from the ruling position he had occupied for almost two decades. For a long time, Kazakhstan was perceived to be a post-Soviet version of smart authoritarianism where wise and balanced leadership had produced economic development and political stability. However, the question is to what degree these dominating narratives reflected the reality of modern Kazakhstan, where stories of economic and political success were often used as a façade to mask deeper structural problems and social tensions.

As with many other authoritarian regimes, Nazarbayev used economic development to legitimize his indefinite stay in power, starting in the mid-1990s when he dismissed the only independent Parliament Kazakhstan has ever had. He aptly summarized his beliefs during the 2015 presidential election, "democracy is not the starting point of our way, it is the final point of our destination" (Tengri News 2015). By the look of macroeconomic indicators, Kazakhstan seems to perform well compared to other post-Soviet states when it comes to GDP growth, poverty rates, and quality of life. Since 1991, Kazakhstan's economy has grown by more than twenty times. In the mid-2000s, Kazakhstan moved from the lower-middle- to the uppermiddle-income category, which is more than can be said for many other former Soviet states.

This economic success is the result of the development during the first two decades of Nazarbayev's rule when resource-rich countries worldwide reaped the benefits of high oil prices. In the 2010s, when oil prices dropped, Kazakhstan's economic growth quickly went into recession largely because of a lack of significant diversification in the country's resource-dependent economy, which was vulnerable to external shocks. Nazarbayev and his elites have tried to address structural weaknesses by launching new reforms and modernization programs, but economic reforms cannot be effective when coupled with weak political institutions, lack of rule of law, and all-pervasive corruption. On February 21, less than a month before his resignation, Nazarbayev indirectly recognized his socioeconomic failures when he fired his cabinet, saying it 
had failed to raise income and living standards for Kazakhstan's citizens (Eurasianet 2019).

Nazarbayev has always touted himself as a wise political leader who has managed to rule a multiethnic nation without any episodes of conflict or violence. The discourse about political stability has been especially emphasized after Russia's annexation of Crimea in 2014 that turned into a protracted conflict with Ukraine. As Nazarbayev said in 2016, "Ukraine, the second-biggest ex-Soviet state, today has an economy which is half the size of Kazakhstan's, because there is no unity" (Reuters 2016, May 1).

It is true that Kazakhstan has been among the few former Soviet states that have not experienced any large-scale mass protests. This led some analysts to believe Kazakhs are satisfied with Nazarbayev's regime. However, there could be another explanation as to why we have not seen mass protests in Kazakhstan.

In 2011, when oil workers protested and demanded a wage raise in the small town of Zhanaozen in Kazakhstan's western Mangystau region, sixteen people-according to official statistics - died as a result of violent clashes with police. Nazarbayev declared a state of emergency in the region, giving law enforcement unlimited authority to make mass arrests, carry out brutal interrogations, and inflict torture. The situation in Zhanaozen is rarely mentioned in discussions about Nazarbayev's Kazakhstan, as this episode clearly falls outside the narrative of a modernizing regime. The crackdown in Zhanaozen sent a clear signal to the people that all serious challenges to the system would be brutally and mercilessly repressed and that the police were loyal to Nazarbayev and would not hesitate to use lethal force against dissenters.

Despite the fear of repression and public disengagement with politics, the past few years have seen multiple protests, including over the devaluation of the national currency, the tenge, in 2014; controversial land reforms in 2016 that allowed foreigners to rent agricultural land in Kazakhstan for twenty-five years; and the "mothers' protests" in 2019 following a fire in Astana that claimed the lives of five children (Radio Free Europe 2019). While these protests have not produced a major uprising, they have all heightened social tension.

\subsection{Post-Nazarbayev Kazakhstan}

The post-Nazarbayev transition is occurring in a strange, slow, and stumbling way. The strange part of the transition is that Nazarbayev still remains in charge of many aspects of the republic's policies. The ministers and local governors report to him regularly, and he meets with international official visitors regularly as well. The current President Tokayev also reports to him regularly. Nazarbayev's portraits remain hanging on the walls in all the offices of government officials.

The slow pace of transition is that the latest changes in the constitution grant huge powers to the first president, even in his current capacity. If officials report to him, it is not a personal loyalty question, and it is a legal process because Nazarbayev is the head of the Security Council. 
The stumbling part of the transition is that it is not clear to people what is going on. The heads of the Presidential Administration have been changed three times since Tokayev stepped into the position. There are some signs of liberalization, but they are contradictory. There are very liberal interviews given to the West by the second president, websites and social media are not blocked, and internet traffic is not slowed down so often as before. At the same time, when people went to the streets after the announcement of the latest presidential elections' results, the police suppressed them as fiercely as usual. And there was the usual fraud during the presidential elections.

Finally, Kazakhstan's society is highly fragmented and divided today, meaning people live in different political and social realities. They are interested in different issues and do not notice issues that are important for the others. Political leaders are aware of these fragmentations and send different messages to these groups. All of the fragmented groups have become agitated after the resignation and expected the new president would take some steps for them as well. All the fragmented groups suddenly felt unified in the search for new conditions in which to coexist with the new authoritarian regime. These new conditions are the future social contract pillars.

\subsection{Conclusion}

Kazakhstan has been a stable authoritarian regime where political power has been held within a very narrow circle of elites close to the president, with the implicit agreement of a population that has not been interested in politics as long as the state could fulfill its social obligations. However, the late 2000s brought a double challenge to the long-term stability and legitimacy of existing social contract-economic stagnation due to the fall of oil prices and uncertainty with Nazarbayev's succession.

Nazarbayev's 2019 resignation was a surprise to many outside and internal observers, and his motivations behind this decision remain widely contested. At first glance, Nazarbayev's resignation may have been motivated by his determination to oversee a peaceful and managed power transition. However, given the growing gap between elites and the ordinary people, the lack of political accountability, and strong public mistrust toward state institutions, Nazarbayev's abrupt departure from power may also be an attempt to preserve his image as the "father of the nation" and an economic modernizer before things start to fall apart.

Given the high levels of inequality and wide public dissatisfaction with political elites, the future social contract in Kazakhstan at the moment remains unclear. Will the public continue to follow ruling elites and allow them to make decisions on behalf of the country, or will there be broader mass mobilization and attempts to challenge a weakened transitional government? The latter scenario that did not happen in Uzbekistan might still occur in more liberal Kazakhstan and would have broader security and geopolitical implications not only for the country but for the entire region - and neighboring Russia — that relies on Kazakhstan as a strategically and partner in the Customs Union. 


\section{References}

Aitken, J. (2010). Nazarbayev and the making of Kazakhstan. London: Continuum.

Akhanov, S., \& Buranbayeva, L. (1996). Foreign investment and trade in Kazakhstan. In B. Kaminski (Ed.), Economic transition in Russian and the New States of Eurasia (pp. 138-59). London: M.E. Sharpe.

Akkuly, S. (2009, November 20). Pojavlenie i raspad DVK posluzhili urokom tolko dlja vlasti. Radio Azattyq.http://rus.azattyq.org/a/Kazakhstan_dvk_round_table/1882932.html. Accessed October 20, 2019.

Akkuly, S. (2011, April 5). Kak Prezident Kazahskoi SSR Nezametno Stal Prezidentom Respubliki Kazahstan. Radio Azattyq. http://rus.azattyq.org/a/kazakhstan_election_nazarbayev_/3546446. html. Accessed October 20, 2019.

Austria Post-Mortem Finds Kazakh Death was Suicide. (2015, February 25). BBC News. http:// www.bbc.co.uk/news/world-europe-31602113. Accessed October 20, 2019.

Bacon, E. (2002). Reconsidering Brezhnev. In E. Bacon \& M. Sandle (Eds.), Brezhnev reconsidered (pp. 1-22). New York: Palgrave.

BBC News. (2016, April 28). Kazakhstan's land reform protests explained. http://www.bbc.co.uk/ news/world-asia-36163103. Accessed October 20, 2019.

Boucher, D., \& Kelly, P. (1994). The social contact and its critics: An overview. In D. Boucher \& P. Kelly (Eds.), The social contract from Hobbes to Rawls (pp. 1-34). London: Routledge.

Breslauer, G. W. (1978). On the adaptability of soviet welfare-state authoritarianism. In K. W. Ryavec (Ed.), Soviet society and the communist party (pp. 3-26). Amherst: The University of Massachusetts Press.

Cummings, S. N. (2005). Kazakhstan: Power and the elites. New York: I.B. Tauris \& Co.

Dave, B. (2007). Kazakhstan: Ethnicity, language and power. London: Routledge.

Eurasianet. (2019, February 21). Kazakhstan: President tells government to step down. https://eurasianet.org/kazakhstan-president-tells-government-to-step-down. Accessed October $20,2019$.

Gorst, I. (2007, August 9). Kazakh exile beats attempt to send him back. The Financial Times. http://www.ft.com/cms/s/0/0afdd74a-4611-11dc-b359-0000779fd2ac.html?ft_site= falcon\&desktop=true\#axzz4O72kTFJp. Accessed October 20, 2019.

Hobson, C., \& Kurki, M. (2012). Introduction: The conceptual politics of democracy promotion. In C. Hobson \& M. Kurki (Eds.), The conceptual politics of democracy promotion (pp. 1-17). New York: Routledge.

Hoen, H. W., \& Irnazarov, F. (2012). Market reform and institutional change in kazakhstan and uzbekistan. paradoxes and prospects. In J. Ahrens \& H. W. Hoen (Eds.), Institutional reform in Central Asia: Politico-economic challenges (pp. 21-43). London: Routledge.

Jowitt, K. (1992). New world disorder: The leninist legacy. Berkeley: University of California Press. Kapital. (2014, November 24). VRK nachat perehod k presidentsko-parlamentskoiforme pravlenija. https://kapital.kz/gosudarstvo/35351/v-rk-nachat-perehod-k-prezidentsko-parlamentskojforme-pravleniya.html. Accessed October 20, 2019.

Kapital. (2015, May 29). Pravitelstvo i Parliament RK poluchat bolshe polnomochiy. https://kapital. kz/gosudarstvo/40739/pravitelstvo-i-parlament-rk-poluchat-bolshe-polnomochij.html. Accessed October 20, 2019.

Kazakhstan. (n.d.). Freedom House. https://freedomhouse.org/sites/default/files/NiT2016_ Kazakhstan.pdf. Accessed October 20, 2019.

Kazinform. (2015, June 2). President Nazarbayev unveils 100 concrete steps to implement five institutional reforms. http://www.inform.kz/en/president-nazarbayev-unveils-100-concrete-steps-toimplement-five-institutional-reforms_a2782614. Accessed October 20, 2019.

Kourmanova, A. (2015, February 5). The Tenge Dilemma in Kazakhstan. Center for Strategic and International Studies. https://www.csis.org/analysis/tenge-dilemma-kazakhstan. Accessed October 20, 2019. 
Malashenko, A. (2013). The fight for influence: Russia in Central Asia. Washington, DC: Carnegie Endowment for International Peace.

McClelland, J. S. (1996). A history of western political thought. London: Routledge.

Nurumov, D., \& Vashchanka, V. (2016). Constitution development of independent Kazakhstan. In R. Elgie \& S. Moestrup (Eds.), Semi-Presidentialism in the Caucasus and Central Asia (pp. 143173). New York: Palgrave.

Olcott, M. B. (2010a). Central Asia's second chance. Washington, DC: Carnegie Endowment for International Peace.

Olcott, M. B. (2010b). Kazakhstan: Unfulfilled promise?. Washington, DC: Carnegie Endowment for International Peace.

OSCE. (2016, March 21). Kazakhstan elections efficiently organized, some progress, still considerable way to go to meet OSCE election commitments, international observers say. https://www. osce.org/odihr/elections/kazakhstan/229136. Accessed October 30, 2019.

Pisano, J. (2014). Pokazukha and cardiologist Khrenov: soviet legacies, legacy theatre, and a usable past. In M. R. Beissinger \& S. Kotkin (Eds.), Historical legacies of communism in Russia and Eastern Europe (pp. 222-243). Cambridge: Cambridge University Press.

Radio Azattyq. (2008, April 2) Nursultan Nazarbayev. http://rus.azattyq.org/a/1187920.html. Accessed October 20, 2019.

Radio Free Europe. (2019, February 12). Tragic fire in Astana gives Kazakh mothers' protests new momentum. https://www.rferl.org/a/tragic-fire-in-astana-gives-kazakh-mothersprotests-new-momentum/29765930.html. Accessed October 20, 2019.

Reuters. (2016, May 1). Kazakh leader evokes Ukraine as land protests spread. http://www.reuters. com/article/us-kazakhstan-protests-president-idUSKCNOXS1E1. Accessed October 20, 2019.

Reuters. (2018, March 3) Putin, before vote, says he'd reverse Soviet collapse if he could: agencies. https://www.reuters.com/article/us-russia-election-putin/putin-before-vote-says-hedreverse-soviet-collapse-if-he-could-agencies-idUSKCN1GE2TF. Accessed October 30, 2019.

RFE Kazakh Europe. (2014, February 15). Kazakh police break up protest against devaluation http://www.rferl.org/a/tenge-protest-almaty-police/25265027.html. Accessed October 20, 2019.

Russkiy Mir v Kazakhstane. (n.d.). Russkiy Mir. http://russkiymir.ru/media/magazines/article/ 141824/. Accessed October 20, 2019.

Sakwa, R. (2014). Putin redux: Power and contradiction in contemporary Russia. London: Routledge.

Seputyte, M., \& Gizitdinov, N. (2015, October 2). Kazakhstan raises new key rate to $16 \%$ to stabilize tenge. Bloomberg. http://www.bloomberg.com/news/articles/2015-10-02/kazakhstan-raisesnew-key-rate-to-16-to-stem-currency-swings. Accessed October 20, 2019.

Sholk, D. (2016, June 15). Kazakhstan's land reforms. The Diplomat. http://thediplomat.com/2016/ 06/kazakhstans-land-reforms/. Accessed October 20, 2019.

Smale, A. (2007, June 2). Kazakh Leader's Defiant Son-in-Law Is Held in Vienna. The New York Times. http://query.nytimes.com/gst/fullpage.html?res= 9B03EFD71330F931A35755C0A9619C8B63. Accessed October 20, 2019.

Tatilja, K. (2016, July 29). Kak otsenivajut grazhdane obschestvenno-politicheskuju situatsiju v strane. Central Asia Monitor. https://camonitor.kz/24619-kak-ocenivayut-grazhdaneobschestvenno-politicheskuyu-situaciyu-v-strane.html. Accessed October 20, 2019.

Tengri News. (2015, March 20). Nazarbayev otsenil svoju rabotu na postu Presidenta. https:// tengrinews.kz/kazakhstan_news/nazarbaev-otsenil-svoyu-rabotu-na-postu-prezidenta-291129/. Accessed October 20, 2019.

Tengri News. (2016, January 6). Nazarbayev napisal statju pro put $k$ novoi kazakhstanskoi mechte. https://tengrinews.kz/kazakhstan_news/nazarbaev-napisal-statyu-put-novoykazahstanskoy-mechte-286834/. Accessed October 20, 2019.

Tengri News. (January 20, 2016) Nazarbayev prizval davat otpor ishushim vinovnyh $v$ uhudshenii situatsii. https://tengrinews.kz/kazakhstan_news/nazarbaev-prizval-davat-otporischuschim-vinovnyih-287610/. Accessed October 20, 2019. 
Tengri News. (2016, June 17). Nazarbayev rasskazal mozhet li Kazakhstan vozglavit zhenshina. https://tengrinews.kz/kazakhstan_news/nazarbaev-rasskazal-mojet-li-kazahstan-vozglavitjenschina-296834/. Accessed October 20, 2019.

Toleukhanova, A. (2016, May 3). Kazakhstan: is land issue foundation for wider anger? Eurasianet. http://www.eurasianet.org/node/78606. Accessed October 20, 2019.

Trifonov, V., \& Rubnikovych, O. (2010, March 19). BTA Bank Zashitili ot Bankira. Kommersant. http://www.kommersant.ru/doc/1339046. Accessed October 20, 2019.

Vlast.kz. https://vlast.kz/novosti/19310-dariga-nazarbaeva-nazvala-spekulaciami-razgovory-otom-cto-avlaetsa-preemnicej-prezidenta.html. Accessed October 20, 2019.

Weber, A., \& Groendahl, B. (2015, February 24). Aliyev, Kazakh who fell out with leader, found hanging. Bloomberg. http://www.bloomberg.com/news/articles/2015-02-24/aliyev-found-deadin-vienna-cell-ahead-of-banker-murder-trial. Accessed October 20, 2019.

Zakaria, F. (1997). Rise of illiberal democracy. Foreign Affairs, 23, 22-43.

Zhandosov, O. (2016, September 22). Government needs more radical measures. Forbes. http://forbes.kz/process/oraz_jandosov_pravitelstvo_rk_doljno_poyti_na_radikalnyie_meryi. Accessed October 20, 2019.

Open Access This chapter is licensed under the terms of the Creative Commons Attribution 4.0 International License (http://creativecommons.org/licenses/by/4.0/), which permits use, sharing, adaptation, distribution and reproduction in any medium or format, as long as you give appropriate credit to the original author(s) and the source, provide a link to the Creative Commons license and indicate if changes were made.

The images or other third party material in this chapter are included in the chapter's Creative Commons license, unless indicated otherwise in a credit line to the material. If material is not included in the chapter's Creative Commons license and your intended use is not permitted by statutory regulation or exceeds the permitted use, you will need to obtain permission directly from the copyright holder.

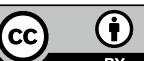

